\title{
Synthesis of alpha-fetoprotein by the pre-implantation and post-implantation bovine embryo*
}

\author{
R. G. Janzen $\dagger$, E. R. Mably $\ddagger$, T. Tamaoki, R. B. Church and \\ F. L. Lorscheider $\ddagger$
}

Departments of Medical Biochemistry and $\ddagger$ Medical Physiology, Faculty of Medicine, University of Calgary, Calgary, Alberta, Canada T2N $4 N 1$

\begin{abstract}
Summary. The synthesis of alpha ${ }_{1}$-fetoprotein (AFP) was measured by radioimmunoassay in tissues and fluids of 19 bovine embryos (14-46 days of gestation) and in tissue cultures of 4 pre-implantation embryos (17-27 days) by incorporation of radioactive methionine. AFP was first detected in Day-14 trophoblasts and secretion of AFP into allantoic fluid occurred by Day 16. Embryonic tissues and fluids in pre-implantation and post-implantation embryos contained levels of AFP that were 550 to 1500000 times higher than those found in maternal serum (3.9-298000 compared with $0.07-0.25 \mathrm{ng} / \mathrm{mg}$ protein). High levels of AFP were also found in uterine fluid which suggested significant transfer of this protein from the early post-implantation conceptus. The major sites of AFP synthesis were yolk sac and fetal liver. It is concluded that the synthesis of bovine AFP is not initiated by events associated with implantation.
\end{abstract}

\section{Introduction}

Alpha-fetoprotein (AFP) is a fetus-specific protein whose origin appears to be the yolk sac and fetal liver in a variety of mammalian species (Gitlin \& Boesman, 1967). This protein is not present in significant quantities in adult tissue unless associated with certain pathological conditions (Ruoslahti \& Seppala, 1979). Studies of mice have demonstrated that AFP mRNA is present in yolk sac (Miura, Law, Nishi \& Tamaoki, 1979; Tilghman, Kioussis, Gorin, Ruiz \& Ingram, 1979) and fetal liver (Koga, O'Keefe, lio \& Tamaoki, 1974), that cultured cells of fetal liver synthesize AFP (Hannah, Simkins \& Eisen, 1980), and that AFP synthesis is limited to the visceral endoderm of the post-implantation embryo (Dziadek \& Adamson, 1978).

The most predominant of three fetus-specific proteins in cattle is $\alpha_{1}$-fetoprotein (Lai, Peters \& Lorscheider, 1978), and the distribution of this protein has been reported in bovine fetal fluids from 42 days until full-term birth at 284 days (Smith, Lai, Robertson, Church \& Lorscheider, 1979). Since methods are now available for the collection of pre-implantation embryos in cows (Church \& Shea, 1977), the objectives of the present investigation were to establish the time of onset of AFP synthesis during early bovine embryogenesis, and specifically to determine whether implantation and placentation precede expression of the AFP gene.

* Reprint requests to: Dr F. L. Lorscheider, Department of Medical Physiology, Faculty of Medicine, University of Calgary, Calgary, Alberta, Canada T2N 4N1.

+ Present address: Department of Molecular, Cellular and Developmental Biology, University of Colorado, Boulder, Colorado, 80309, U.S.A. 


\section{Materials and Methods}

Nineteen nulliparous cows of mixed breeding were inseminated $12 \mathrm{~h}$ after standing heat on the day of oestrus (Day 0) (Church \& Shea, 1977). Pregnant cows from Alberta Livestock Transplants (Calgary, Alberta) were slaughtered on the days indicated in Table 1 and the reproductive tract removed immediately. All gravid uterine horns were carefully opened and pinned out flat. Day 14 to 20 trophoblasts were flushed from the open horn with $2 \mathrm{ml}$ phosphate buffered saline (PBS) (pH 7.1) with a large bore Pasteur pipette. Uterine fluid was obtained by flushing the exposed maternal epithelium with 5-10 ml PBS. Conceptuses of $\geq 22$ days were flushed from the exposed uterine horn following careful total withdrawal of allantoic and amniotic fluids with perfusion syringes. Conceptus membranes were carefully dissected away from the embryo under a Wild M5 microscope. Conceptuses showing evidence of caruncle attachment were dissected from the gravid uterine horn in their entirety after removal of extra-embryonic fluids.

AFP synthesis was quantitatively determined by radioimmunoassay (Lai, Smith, Church \& Lorscheider, 1979) and the results were expressed in ng AFP/mg tissue protein. Total protein determinations in each sonicated tissue or fluid were performed as described by Lowry, Rosebrough, Farr \& Randall (1951). AFP synthesis was also qualitatively determined by tissue culture of 4 pre-implantation embryos (17 and 27 days) in which the incorporation of radiolabelled methionine into AFP was detected by fluorography of the electrophoresed immunoprecipitates. Control experiments such as the use of non-specific antibodies or prior absorption of anti-fetal calf serum by the addition of excess AFP were performed to verify the results. Embryos or separate whole tissues were placed in $1 \mathrm{ml}$ chilled $15 \mathrm{mM}-\mathrm{NaPO}_{4} / 150$ $\mathrm{mM}-\mathrm{NaCl}(\mathrm{pH} 7 \cdot 2)$, recovered by centrifugation $(500 \mathrm{~g})$ and washed twice with Eagles Minimal Essential Medium (GIBCO, Madison, Wisconsin, U.S.A.) with non-essential amino acids containing $15 \mathrm{mM}$-Hepes buffer, $100 \mathrm{U}$ penicillin $/ \mathrm{ml}$ and $100 \mu \mathrm{g}$ streptomycin $/ \mathrm{ml} \mathrm{at} 37^{\circ} \mathrm{C}$. Each tissue was cultured for $30 \mathrm{~min}$ at $37^{\circ} \mathrm{C}$ in $250 \mu \mathrm{l}$ of the above medium in $12 \times 75 \mathrm{~mm}$ sterile culture tubes in air. The medium was then changed to one in which methionine was replaced by $50 \mu \mathrm{Ci}\left[{ }^{35} \mathrm{~S}\right]$ methionine $/ \mathrm{ml}$ (sp. act. $934 \mathrm{Ci} / \mathrm{mmol}$; New England Nuclear, Boston, Massachusetts, U.S.A.). Incubation was continued for $1 \mathrm{~h}$, then sodium deoxycholate and Triton-X 100 were added to a final concentration of $0.5 \%$ each and tissues were rapidly frozen and thawed 3 times. The detergent concentrations were increased to $1 \%$ each and freezing and thawing was repeated 3 more times after which the sample was centrifuged in a Beckman Microfuge at $10000 \mathrm{~g}$ for $5 \mathrm{~min}$ at $4^{\circ} \mathrm{C}$ and the supernatant from the cell lysate was stored at $-70^{\circ} \mathrm{C}$. After thawing, $50 \mu$ of the supernatant were incubated with $75 \mu$ l bovine amniotic fluid $\left(48.7 \mu \mathrm{g} \mathrm{AFP} / \mathrm{ml}\right.$ ) and $40 \mu \mathrm{l}$ rabbit anti-fetal calf serum (Lai et al., 1978) for $60 \mathrm{~min}$ at $28^{\circ} \mathrm{C}$ and $18 \mathrm{~h}$ at $4^{\circ} \mathrm{C}$. Then $150 \mu \mathrm{l}$ goat anti-rabbit $\gamma$-globulin $(2$ units; Calbiochem, San Diego, California, U.S.A.) and $75 \mu \mathrm{l}$ normal rabbit serum were added and incubation was continued for $1 \mathrm{~h}$ at $28^{\circ} \mathrm{C}$ and overnight at $4^{\circ} \mathrm{C}$. The precipitate was washed by re-suspending in $100 \mu \mathrm{l}$ phosphate-buffered saline solution containing $1 \%$ sodium deoxycholate, $1 \%$ Triton-X100 and 1 $\mathrm{mM}$-methionine and then centrifuging through the same solution containing $0.9 \mathrm{M}$-sucrose (Miura et al., 1979). This procedure was repeated twice, after which the precipitate was dissolved in SDS buffer (Laemmli, 1970) at $90^{\circ} \mathrm{C}$ for $15 \mathrm{~min}$ and the radioactivity in a $5 \mu$ laliquot of this solution was determined.

Equal counts of the radioactive immunoprecipitates were applied to each lane of an $8-16 \%$ gradient SDS polyacrylamide slab-gel using the Laemmli (1970) buffer. A current of $10 \mathrm{~mA}$ per gel was used until the tracking dye front had passed through the stacking gel, after which the current was increased to $20 \mathrm{~mA}$. Bovine $\alpha_{1}$-fetoprotein (Lai et al., 1978) was employed as the reference standard. The gel was stained with $0.05 \%$ Coomassie Brilliant Blue (G250) in methanol-water-glacial acetic acid (5:5:1 by vol.) for $2 \mathrm{~h}$ before destaining. Radioactive bands were detected by fluorography using Kodak XR-1 X-ray film and a 2-day exposure as described by Lasky \& Mills (1975). 
In one experiment the yolk sac lysate from a 27-day pre-implantation embryo was immunoprecipitated using a monospecific antiserum against bovine AFP (Lai et al., 1978). The total precipitable radioactivity was electrophoresed and fluorography was performed as described above with a 3-day exposure.

\section{Results}

Table 1 lists the levels of AFP ( $\mathrm{ng} / \mathrm{mg}$ protein) found in tissues and fluids of the bovine embryo and maternal serum from 14 to 46 days of gestation. Embryo tissues displayed a marked increase in AFP concentration with advance of gestation but concentrations of maternal serum AFP remained similar to those found in non-pregnant cows. The embryo tissue and fluid values were approximately 550 to 1500000 times higher than those found in maternal serum. Concentrations were higher in fetal blood and uterine fluid than in maternal serum, especially after implantation.

Table 1. Ranges* of concentrations (ng/mg protein) of alpha-fetoprotein in tissues and fluids of the bovine embryo during early development

\begin{tabular}{|c|c|c|c|c|c|}
\hline \multirow[b]{2}{*}{ Specimen } & \multicolumn{5}{|c|}{ Gestational age (days) } \\
\hline & $14-22$ & $\begin{array}{c}25-27 \\
\text { (pre-implantation) }\end{array}$ & $\begin{array}{c}25-27 \\
\text { (post-implantation) }\end{array}$ & $31-36$ & $40-46$ \\
\hline Embryo (whole) & $3.91-6.68+(14$ days $)$ & $29100-42800$ & $20800-59700$ & $27800-136000$ & $17200-142000$ \\
\hline Allantoic fluid & 220 ( 16 days) & $18000-60300$ & $24900-33700$ & $16800-62800$ & $17500-41900$ \\
\hline Yolk sac & NA & $59700^{\dagger}$ & NA & 40800 & NA \\
\hline Fetal liver & NA & $110-1080+$ & $8660-20900$ & $119000-298000$ & $12700-130000$ \\
\hline Amniotic fluid & NA & 233000 & $80000-212000$ & $41200-208000$ & $41400-190000$ \\
\hline $\begin{array}{l}\text { Conceptus } \\
\text { membranes }\end{array}$ & NA & 27300 & $14600-25900$ & $6130-10800$ & $10600-11700$ \\
\hline Fetal blood & NA & NA & NA & $450-74700$ & NA \\
\hline Uterine fluid & $290-549$ & NA & 24300 & $29200-40200$ & $55700-84700$ \\
\hline Maternal serum $f$ & $0.07-0.19$ & 0.21 & 0.21 & $0.16-0.19$ & $0.09-0.25$ \\
\hline
\end{tabular}

NA, not available.

* Ranges of values represent samples from embryos recovered from 2-4 cows, unless one value for a single animal is given.

+ Supernatant of cell culture lysate (see text).

$\ddagger$ Range of values for non-pregnant cow serum: $0 \cdot 1 \mathrm{t}-0.35 \mathrm{ng} / \mathrm{mg}$ protein.

As shown in Text-fig. 1, the major site of AFP synthesis was the yolk sac with a significant but lesser amount of synthesis being evident in fetal liver. Fetal gut tissue appeared to have a trace amount of AFP synthesis which was not detectable in brain or allantoic membrane. Various minor protein bands, which did not migrate adjacent to the immunoprecipitate of the purified bovine AFP standard, reflected precipitation of other fetal serum proteins by the rabbit anti-fetal calf serum.

Use of the monospecific antiserum (Text-fig. 2) revealed a major protein band which migrated adjacent to the immunoprecipitate of the bovine AFP standard, confirming the synthesis of AFP in the pre-implantation embryo.

Synthesis of AFP relative to total protein synthesis was estimated by precipitating an aliquot of the radioactive lysate supernatant with hot trichloroacetic acid (TCA) and expressing results as the ratio of radioactivity in the immunoprecipitate to that in the TCA precipitate. Such calculations revealed that in two 17-day pre-implantation embryos AFP synthesis was $<0.1 \%$ of the total protein. In contrast, a 27-day pre-implantation embryo displayed AFP synthesis of $8.4 \%$ in yolk sac and $0.5 \%$ in liver when rabbit anti-fetal calf serum was used (Text-fig. 1) and $3.7 \%$ in yolk sac with a monospecific antiserum (Text-fig. 2 ). 


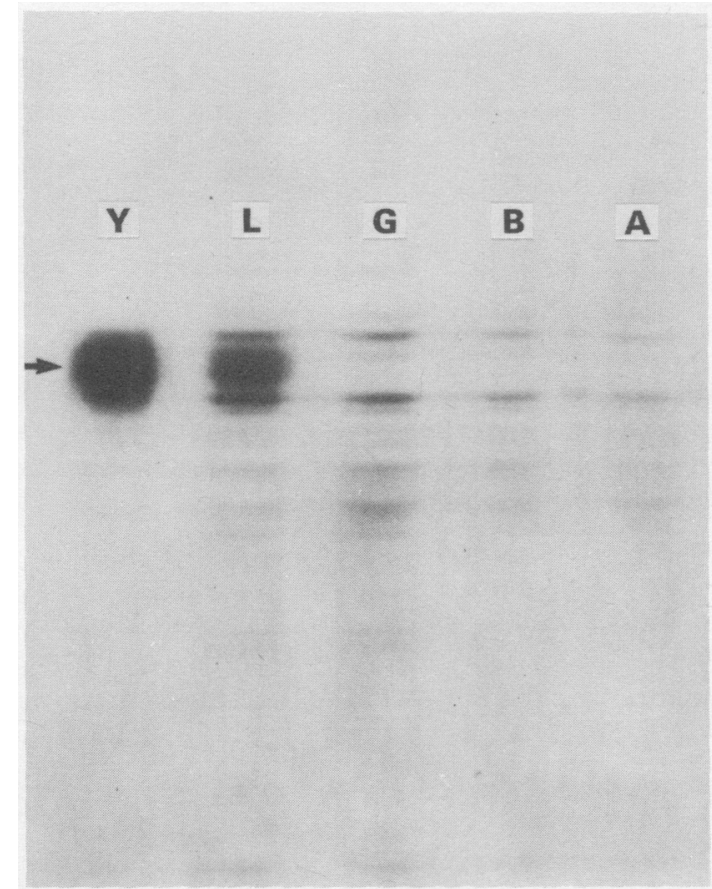

Text-fig. 1. Fluorogram of radioactive immunoprecipitates from cultures of 27-day bovine pre-implantation embryo tissues. Precipitation was achieved using rabbit anti-fetal calf serum. The arrow indicates the position of migration for non-radioactive purified bovine AFP standard. Y, yolk sac; L, fetal liver; G, fetal gut; B, fetal brain; A, allantoic membrane.

Text-fig. 2. Fluorogram of radioactive immunoprecipitate from culture of the yolk sac of a 27-day bovine pre-implantation embryo. Precipitation was achieved using a monospecific antiserum to AFP. The arrow indicates the position of migration for non-radioactive purified bovine AFP standard.

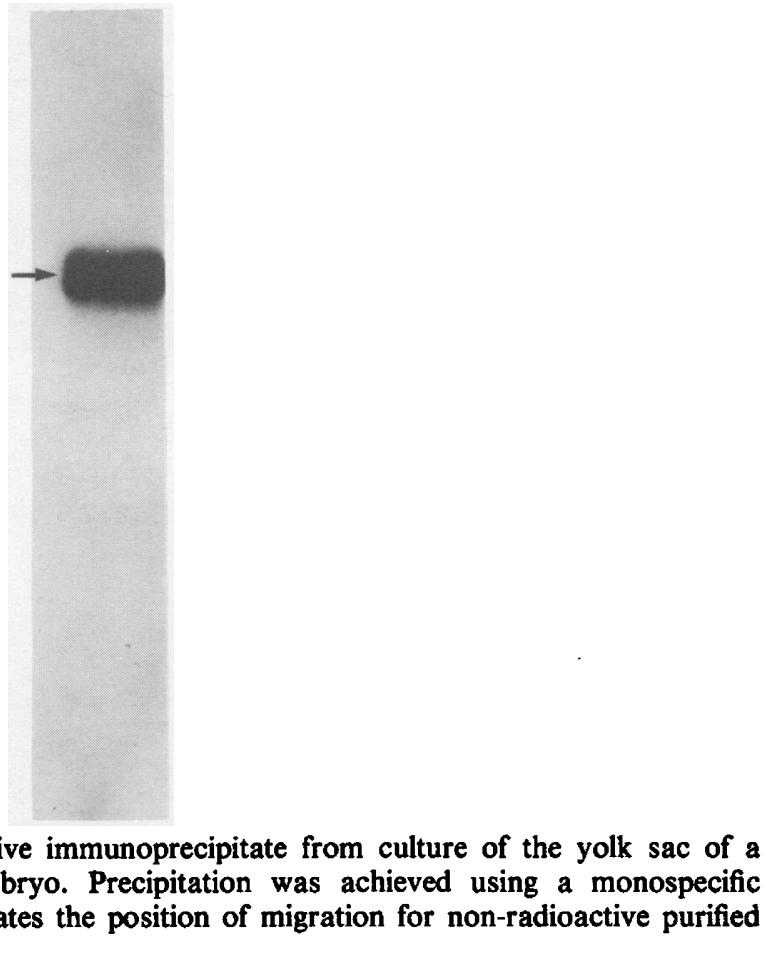




\section{Discussion}

The morphology of the bovine embryo from Days 16 to 26 of gestation has been described in detail (Greenstein \& Foley, 1958), and implantation occurs over 8-10 days with placentomes being present by Day 31 (Melton, Berry \& Butler, 1951; King, Atkinson \& Robertson, 1981). The placenta is of the epitheliochorial type (Eckstein \& Kelly, 1977). In this study we classified an embryo as being post-implantation on the basis of presumptive attachment manifest by the first sign of loss of surface epithelium from the uterine caruncles in a chemotactic response to cones of trophoblastic cells on the chorio-allantoic membrane (Melton et al., 1951). With this classification 2 of the embryos at 25 and 27 days gestation were designated as post-implantation, while 2 other embryos of the same gestational age were considered to be of pre-implantation status.

The results of the present investigation clearly indicate that several tissues and fluids of the pre-implantation bovine conceptus synthesize or accumulate high levels of AFP. The presence of AFP in two 14-day embryos (Table 1) reflected synthesis of this protein by the late trophoblast stage. By Day 16 AFP was evident in allantoic fluid. Pre-implantation embryos from Days 25 to 27 of gestation showed markedly elevated levels of AFP in all conceptus tissues and fluids which were assayed and the protein was still present in the same embryonic sites after implantation. Since maternal blood levels of AFP remained low, the high levels of AFP detected in uterine fluid suggest that an appreciable amount of AFP is transferred from the early conceptus, perhaps by transudation across primitive embryonic membranes.

Fluorography was first attempted on radioactive cultures from two 17-day embryos and the results indicated that AFP synthesis was $<0.1 \%$ of total protein synthesis. However, cultures of 27-day-old pre-implantation embryo tissue (Text-fig. 1) and the parallel radioimmunoassay results (Table 1) clearly demonstrate that the major site of synthesis is the yolk sac with a significant but lesser contribution from the fetal liver. This latter finding is consistent with the observation that AFP mRNA levels are higher in rat yolk sac compared to fetal liver (Liao, Conn \& Taylor, 1980). Since cultured cells of allantoic membrane showed no evidence of AFP synthesis (Text-fig. 1) but high levels of AFP were detected in allantoic fluid and membranes (Table 1) of the pre-implantation embryo, it seems probable that AFP is secreted by visceral endoderm cells into the allantoic fluid whence it is subsequently absorbed or taken up by membrane cells. The relatively high levels of AFP in amniotic fluid from 25 to 46 days (Table 1) may be attributed in part to a low concentration of total protein in this fluid which would, in effect, elevate the ratio of AFP to total protein.

In conclusion, AFP synthesis in the bovine embryo begins well in advance of implantation and is not restricted to the post-implantation embryo as reported for the mouse (Dziadek \& Adamson, 1978). This difference may be due to technical difficulties in establishing the presence of AFP in the much smaller mouse embryo. AFP has been suggested to have an immunosuppressive role mediated by several mechanisms (reviewed by Suzuki \& Tomasi, 1980). The presence of AFP in the bovine trophoblast could indicate that this fetal protein may act at the site of implantation, perhaps to enhance survival of the fetal allograft. This study demonstrates the first example of expression of a single conceptus-specific gene product that has been quantitatively monitored in a pre-implantation embryo.

This study was supported by research grants from the Alberta Children's Hospital Foundation, the Medical Research Council, the National Cancer Institute of Canada, the Alberta Heritage Savings Trust Fund, and the Natural Sciences and Engineering Research Council. We thank Dr D. Dyrholm of Alberta Livestock Transplants and K. M. Raines for their assistance. T.T. is a research associate of the National Cancer Institute of Canada. 


\section{References}

Church, R.B. \& Shea, B.F. (1977) The role of embryo transfer in animal improvement programs. Can. $J$. Anim. Sci. 57, 33-45.

Dziadek, M. \& Adamson, E. (1978) Localization and synthesis of alphafoetoprotein in post-implantation mouse embryos. J. Embryol. exp. Morph. 43, 289-313.

Eckstein, P. \& Kelly, W.A. (1977) Implantation and development of the conceptus. In Reproduction in Domestic Animals 3rd edn, pp. 329-331. Eds P. T. Cupps \& H. H. Cole. Academic Press, New York.

Gitlin, D. \& Boesman, M. (1967) Fetus-specific serum proteins in several mammals and their relation to human $\alpha$-fetoprotein. Comp. Biochem. Physiol. 21, 327-336.

Greenstein, J.S. \& Foley, R.C. (1958) The early embryology of the cow with notes on comparable human development. Int. J. Fertil. 3, 67-78.

Hannah, R., Simkins, R. \& Eisen, J. (1980) Synthesis of $\alpha$-fetoprotein and albumin by fetal mouse liver cultured in chemically defined medium. Devl Biol. 77, 244-252.

King, G. J., Atkinson, B. A. \& Robertson, H. A. (1981) Development of the intercaruncular areas during early gestation and establishment of the bovine placenta. J. Reprod. Fert. 61, 469-474.

Koga, K., O'Keefe, D.W., Iio, T. \& Tamaoki, T. (1974) Transcriptional control of $\alpha$-fetoprotein synthesis in developing mouse liver. Nature, Lond. 252, 495-497.

Laemmli, U.K. (1970) Cleavage of structural proteins during the assembly of the head of bacteriophage T4. Nature, Lond. 227, 680-685.

Lai, P.C.W., Peters, E.H. \& Lorscheider, F.L. (1978) Bovine fetus-specific serum proteins: purification and characterization of $\alpha_{1}$-fetoprotein and immunological identification of $\alpha_{2^{-}}$and $\beta$-fetoproteins. Biochim. Biophys. Acta 535, 138-149.

Lai, P.C.W., Smith, K.M., Church, R.B. \& Lorscheider,
F.L. (1979) Radioimmunoassay of bovine alpha $a_{1}$ fetoprotein in maternal plasma during pregnancy and in newborn calf plasma. In Carcino-Embryonic Proteins II, pp. 309-315. Ed. F. G. Lehmann. Elsevier Press, Amsterdam.

Lasky, R.A. \& Mills, A.D. (1975) Quantitative film detection of ${ }^{3} \mathrm{H}$ and ${ }^{14} \mathrm{C}$ in polyacrylamide gels by fluorography. Eur.J. Biochem. 56, 335-341.

Liao, W.S.L., Conn, A.R. \& Taylor, J.M. (1980) Changes in rat $a_{3}$-fetoprotein and albumin mRNA levels during fetal and neonatal development. J. biol. Chem. 255, 10036-10039.

Lowry, O.H., Rosebrough, N.J., Farr, A.L. \& Randall, R.J. (1951) Protein measurement with the folin phenol reagent. J. biol. Chem. 193, 265-275.

Melton, A.A., Berry, R.O. \& Butler, O.D. (1951) The interval between the time of ovulation and attachment of the bovine embryo. J. Anim. Sci. 10, 993-1005.

Miura, K., Law, S.W.T., Nishi, S. \& Tamaoki, T. (1979) Isolation of $\alpha$-fetoprotein messenger RNA from mouse yolk sac. J. biol. Chem. 254, 5515-5521.

Ruoslahti, E. \& Seppala, M. (1979) Alpha-fetoprotein in cancer and fetal development. Adv. Cancer Res. 29, $275-346$.

Smith, K.M., Lai, P.C.W., Robertson, H.A., Church, R.B. \& Lorscheider, F.L. (1979) Distribution of alpha $a_{1}$-fetoprotein in fetal plasma, allantoic fluid, amniotic fluid and maternal plasma of cows. $J$. Reprod. Fert. 57, 235-238.

Suzuki, K. \& Tomasi, T.B. (1980) Mechanism of immune suppression by murine neonatal fluids. $J$. Immunol. 125, 1806-1810.

Tilghman, S.M., Kioussis, D., Gorin, M.B., Ruiz, J.P.G. \& Ingram, R.S. (1979) The presence of intervening sequences in the $\alpha$-fetoprotein gene of the mouse. $J$. biol. Chem. 254, 7393-7399.

Received 15 June 1981 